\title{
SUNFLOWER MEAL AND EXOGENOUS ENZYMES IN INITIAL DIETS FOR BROILERS $^{1}$
}

\author{
TACIANA MARIA MORAES DE OLIVEIRA ${ }^{2}$, RICARDO VIANNA NUNES $^{3}$, CINTHIA EYNG $^{3}$, EVELINE $^{3}$ \\ BERWANGER $^{4}$, DOUGLAS FERNANDO BAYERLE ${ }^{3}$
}

\begin{abstract}
This research aimed to evaluate the effects of different levels of sunflower meal (SFM) and the supplementation of a multienzyme complex in the initial diets of broilers on their performance, intestinal morphometry and carcass characteristics. In all, 11001 -d-old male chicks were distributed in a completely randomized design with $2 \times 5$ factorial arrangement (with and without a multienzyme supplement and five levels of SFM inclusion - 0, 4, 8, 12 and 16\%), and five replications per experimental unit. The experimental diets were provided until the chickens were 21 -d-old and thereafter all birds received the same diet up to $42 \mathrm{~d}$, to evaluate the possible residual effects of treatments. The SFM inclusion impaired performance from 1 to $21 \mathrm{~d}$ of age and the animals that received SFM during the initial phase, failed to recover from the negative effects on performance parameters. The multienzyme supplement improved the intestinal morphometry and was more effective than non-supplemented diets on performance, independent of the SFM inclusion level. The carcass and cuts yield of the wings and leg were significantly affected by the multienzyme supplementation. In conclusion, the SFM inclusion impaired performance variables and intestinal morphometry without affecting carcass yield; however, the supplementation of an enzyme complex counteracted the negative performance and intestinal morphometry effects.
\end{abstract}

Keywords: Alternative food. Intestinal morphometry. Nutritional quality. Performance.

\section{FARELO DE GIRASSOL E ENZIMAS EXÓGENAS EM RAÇÕES INICIAIS PARA FRANGOS DE CORTE}

RESUMO - Esta pesquisa objetivou avaliar o efeito de diferentes níveis de farelo de girassol (FG) e suplementação de complexo multienzimático em rações iniciais para frangos de corte sobre o desempenho, morfometria intestinal e características de carcaça. Ao todo, 1100 pintos machos de um dia de idade foram distribuídos em um delineamento inteiramente casualizado em esquema fatorial 2 x 5 (com e sem a suplementação do complexo multienzimático e cinco níveis de inclusão de FG - 0, 4, 8, 12 e 16\%), com cinco repetições por unidade experimental. As dietas experimentais foram fornecidas até os 21 dias e posteriormente todas as aves receberam a mesma dieta até os 42 dias, a fim de avaliar possíveis efeitos residuais dos tratamentos. A inclusão de FG prejudicou o desempenho de 1 a 21 dias de idade sendo que os animais que receberam FG durante a fase inicial falharam em recuperar os efeitos negativos nos parâmetros de desempenho. A inclusão de enzimas nas dietas melhorou a morfometria intestinal sendo mais efetiva sobre os parâmetros de desempenho do que as dietas que não haviam sido suplementadas, independente do nível de inclusão do FG. O rendimento de carcaça e o rendimento dos cortes, asas e perna, foram significativamente afetados pela suplementação multienzimática. Em conclusão, a inclusão de FG prejudicou as variáveis de desempenho e morfometria intestinal sem afetar o rendimento de carcaça. No entanto, a adição do complexo multienzimático recuperou os efeitos negativos sobre o desempenho e morfometria intestinal.

Palavras-chave: Desempenho. Alimento alternativo. Morfometria intestinal. Qualidade nutricional.

\footnotetext{
*Corresponding author

${ }^{1}$ Received for publication in $04 / 24 / 2015$; accepted in $06 / 17 / 2016$

Paper extracted from the master dissertation of the first author.

${ }^{2}$ Department of Animal Science, Universidade Estadual de Maringá, Maringá, PR, Brazil; tacideoliveira@hotmail.com.

${ }^{3}$ Department of Animal Science, Universidade Estadual do Oeste do Paraná, Marechal Cândido Rondon, PR, Brazil; nunesrv@hotmail.com, cinthiaeyng@hotmail.com, douglasbayerle@hotmail.com.

${ }^{4}$ Department of Animal Science, Universidade Federal do Rio Grande do Sul, Porto Alegre, RS, Brazil; evelineberwanger@hotmail.com.
} 


\section{INTRODUCTION}

The poultry production chain is faced with the significant challenge of manufacturing high-quality poultry meat at low cost. Thus, nutritionists are constantly searching for alternative ingredients for poultry diets to replace those commonly used, such as corn and soybean meal, but that also meet the nutritional requirements of birds.

Sunflower meal (SFM) has been recognized as an alternative source of protein in animal nutrition. This ingredient can be characterized as a byproduct obtained after the continuous oil extraction of sunflower seeds by organic solvents, subjected to roasting and cooling (OLIVEIRA et al., 2014). Although SFM has no toxic compounds and contains higher levels of calcium, phosphorus and methionine compared to soybean meal, it is high in fiber and lysine deficient, which may limit its inclusion in poultry diets (BRENES et al., 2008).

Several previous studies have attempted to establish the optimal level of SFM inclusion in broiler diets (RAMA RAO et al., 2006; SENKOYLU; DALE, 2006; RAZA et al., 2009). Rama Rao et al. (2006) found that replacing soybean meal with $67 \%$ SFM in starter diets and $100 \%$ replacement in finisher diets did not affect weight gain, however, feed efficiency was decreased. Moghaddam et al. (2012) reported no significant difference in feed intake or weight gain when broiler diets contained up to $14 \%$ SFM from 1 to $21 \mathrm{~d}$ and from 22 to $42 \mathrm{~d}$ of age.

The reported levels of SFM are variable and their effects on broiler performance are highly dependent on the chemical composition and energy value of the SFM used, as well as the age of the studied birds (SENKOYLU; DALE, 2006). However, the addition of commercial enzyme complexes to the diets containing SFM could improve the nutrient availability and metabolizable energy content by increasing the amount of nutrients accessible to digestive enzymes. Some studies detected positive effects of enzyme supplementation on nutrient absorption and broiler performance in birds fed diets containing SFM (KOCHER et al., 2000; MUSHTAQ et al., 2009).

Thus, the present study evaluated the effects of different levels of dietary SFM inclusion and a multienzyme supplement in the initial diets for broilers on their performance, intestinal morphometry and carcass characteristics.

\section{MATERIAL AND METHODS}

The experiment was conducted on the experimental farm of the West Parana State University, State of Paraná, Brazil (Universidade Estadual do Oeste do Paraná, Paraná) with the approval of the Institutional Animal Care and Use Committee, which oversees research with animal subjects at university facilities.

In all, 1,100 1-d-old, male $\mathrm{Cobb}^{\circledR}$ chicks were distributed in a completely randomized design with 2 x 5 factorial arrangement (with or without addition of $0.2 \mathrm{~g} . \mathrm{kg}^{-1}$ of a multienzyme complex (pectinase $4000 \mathrm{ug}^{-1}$, protease - $700 \mathrm{ug}^{-1}$, phytase - $300 \mathrm{ug}^{-1}$, glucanase - $200 \mathrm{ug}^{-1}$, xylanase - $100 \mathrm{ug}^{-1}$, cellulase $40 \mathrm{ug}^{-1}$, and amylase - $30 \mathrm{ug}^{-1}$ ) and five SFM inclusion levels - 0, 4, 8, 12 and $16 \%$, chosen by adequacy of diet formulations), and five replications per experimental unit.

The birds were provided ad libitum access to water and the experimental diets, throughout all experimental periods. The nutritional values of SFM proposed by Oliveira et al. (2014) were adopted. The diets were formulated according to Rostagno et al. (2011) for the average performance of male broilers from 1 to $7 \mathrm{~d}$ of age and from 8 to $21 \mathrm{~d}$ (Tabela 1 and 2).

Experimental diets were supplied until $21 \mathrm{~d}$ of age. The birds were then placed on a conventional diet containing $3,150 \mathrm{kcal} . \mathrm{kg}^{-1}$ of metabolizable energy (ME) and $19.8 \%$ crude protein (CP) from 22 to $35 \mathrm{~d}$ of age and a diet containing $3,200 \mathrm{kcal} . \mathrm{kg}^{-1}$ $\mathrm{ME}$ and $18.4 \% \mathrm{CP}$ until $42 \mathrm{~d}$ of age, offered equally to all birds. These diets were based on corn and soybean meal and were formulated using the feed chemical composition values and the nutritional requirements for the average performance of male broilers, according to Rostagno et al. (2011). The broilers and the feed were weighed at 1,21 and $42 \mathrm{~d}$ of age to calculate broiler performance, which was measured as the weight gain, feed intake and feed conversion rate.

At $21 \mathrm{~d}$ of age, two birds per experimental unit ( $\pm 5 \%$ average weight - starved for $8 \mathrm{~h}$ ), were slaughtered by cervical dislocation and then samples were collected from the duodenum, jejunum and ileum for morphometric analysis. The intestinal fragments (approximately $5 \mathrm{~cm}$ ) from each segment were then placed on polystyrene sheets, opened longitudinally, washed in saline solution, fixed in $10 \%$ formaldehyde solution, dehydrated and embedded in paraffin. Thin sections from each segment were cut at a thickness of $7 \mu \mathrm{m}$ and stained with hematoxylin and eosin, according to Luna (1968). The slides were visualized using a light microscope and analyzed by Image Pro-Plus software. The height of 30 villi and depth of 30 crypts were recorded from each segment, with duplicate measurements. 
Table 1. Percentual and calculated composition of experimental diets used from 1 to $7 \mathrm{~d}$-old.

\begin{tabular}{|c|c|c|c|c|c|}
\hline \multirow{2}{*}{ Ingredient $\left(\mathrm{g} \cdot \mathrm{kg}^{-1}\right)$} & \multicolumn{5}{|c|}{ Sunflower level of inclusion (\%) } \\
\hline & 0 & 4 & 8 & 12 & 16 \\
\hline Corn grain & 552.81 & 543.36 & 539.75 & 521.60 & 504.10 \\
\hline Soybean meal & 372.96 & 327.11 & 264.35 & 231.75 & 199.51 \\
\hline Sunflower meal & 0.00 & 40.00 & 80.00 & 120.00 & 160.00 \\
\hline Corn gluten $60 \%$ & 8.00 & 15.00 & 40.32 & 43.00 & 45.35 \\
\hline Soy oil & 20.50 & 25.00 & 27.00 & 35.00 & 42.27 \\
\hline Dicalcium & 19.15 & 18.88 & 18.73 & 18.35 & 17.96 \\
\hline Limestone & 9.13 & 9.25 & 9.38 & 9.50 & 9.62 \\
\hline Salt & 5.07 & 5.07 & 5.08 & 5.09 & 5.09 \\
\hline DL-methionine & 3.60 & 3.40 & 2.95 & 2.72 & 2.49 \\
\hline L-lysine $\mathrm{HCl}$ & 3.27 & 3.91 & 4.89 & 5.17 & 5.43 \\
\hline L-threonine & 1.22 & 1.31 & 1.28 & 1.26 & 1.22 \\
\hline L-valine & 0.82 & 0.93 & 0.86 & 0.85 & 0.83 \\
\hline L-arginine & 0.30 & 0.87 & 1.63 & 1.86 & 2.10 \\
\hline L-tryptophane & 0.00 & 0.02 & 0.07 & 0.13 & 0.19 \\
\hline L-isoleucine & 0.00 & 0.41 & 0.51 & 0.61 & 0.70 \\
\hline Vitamin suplement $^{1}$ & 1.00 & 1.00 & 1.00 & 1.00 & 1.00 \\
\hline Mineral suplemento $^{2}$ & 0.50 & 0.50 & 0.50 & 0.50 & 0.50 \\
\hline Choline chloride $60 \%$ & 0.60 & 0.60 & 0.60 & 0.60 & 0.60 \\
\hline Anticoccidial $^{3}$ & 0.60 & 0.60 & 0.60 & 0.60 & 0.60 \\
\hline Antioxidant $^{4}$ & 0.20 & 0.20 & 0.20 & 0.20 & 0.20 \\
\hline Growth promoter ${ }^{5}$ & 0.10 & 0.10 & 0.10 & 0.10 & 0.10 \\
\hline Multienzimatic complex or Inert ${ }^{6}$ & 0.20 & 0.20 & 0.20 & 0.20 & 0.20 \\
\hline \multicolumn{6}{|l|}{ Calculated composition } \\
\hline Metabolizable Energy $\left(\mathrm{kcal} \mathrm{kg}^{-1}\right)$ & 2900 & 2900 & 2900 & 2900 & 2900 \\
\hline Crude Protein $\left(\mathrm{g} \cdot \mathrm{kg}^{-1}\right)$ & 224.00 & 224.00 & 224.00 & 224.00 & 224.00 \\
\hline Calcium $\left(\mathrm{g} \cdot \mathrm{kg}^{-1}\right)$ & 9.20 & 9.20 & 9.20 & 9.20 & 9.20 \\
\hline Available phosphorous (g. $\left.\mathrm{kg}^{-1}\right)$ & 4.70 & 4.70 & 4.70 & 4.70 & 4.70 \\
\hline Sodium $\left(g \cdot \mathrm{kg}^{-1}\right)$ & 2.20 & 2.20 & 2.20 & 2.20 & 2.20 \\
\hline Cloride $\left(\mathrm{g} \cdot \mathrm{kg}^{-1}\right)$ & 2.00 & 3.50 & 3.50 & 3.50 & 3.50 \\
\hline Potassium $\left(\mathrm{g} \cdot \mathrm{kg}^{-1}\right)$ & 8.35 & 7.95 & 7.99 & 7.86 & 7.73 \\
\hline Neutral detergent fiber - NDF $\left(\mathrm{g} \cdot \mathrm{kg}^{-1}\right)$ & 117,89 & 125,01 & 131,67 & 139,31 & 147,06 \\
\hline Acid detergente fibre - ADF (g. $\left.\mathrm{kg}^{-1}\right)$ & 49,47 & 54,97 & 60,89 & 66,80 & 72,73 \\
\hline Digestible Lysine $\left(\mathrm{g} \cdot \mathrm{kg}^{-1}\right)$ & 13.24 & 13.24 & 13.24 & 13.24 & 13.24 \\
\hline Digestible Methyonine + Cystin $\left(\mathrm{g} \cdot \mathrm{kg}^{-1}\right)$ & 9.53 & 9.53 & 9.53 & 9.53 & 9.53 \\
\hline Digestible Threonine $\left(\mathrm{g}^{\mathrm{kg}} \mathrm{kg}^{-1}\right)$ & 8.61 & 8.61 & 8.61 & 8.61 & 8.61 \\
\hline Digestible Valine $\left(\mathrm{g} \cdot \mathrm{kg}^{-1}\right)$ & 10.20 & 10.20 & 10.20 & 10.20 & 10.20 \\
\hline Digestible Isoleucine (g.kg $\left.{ }^{-1}\right)$ & 8.87 & 8.87 & 8.87 & 8.87 & 8.87 \\
\hline Digestible Arginine (g.kg-1) & 14.30 & 14.30 & 14.30 & 14.30 & 14.30 \\
\hline Digestible Tryptophan (g.kg $\left.{ }^{-1}\right)$ & 2.25 & 2.25 & 2.25 & 2.25 & 2.25 \\
\hline
\end{tabular}

${ }^{1}$ Content: Vit A - 10.000.000 UI; Vit D3 - 2.000.000UI; Vit E - 30.000UI; Vit B1 - 2.0g; Vit B6 - 4.0g; Pantotenic acid 12.0g; Biotine - 0.10g; Vit K3 - 3.0g; Folic acid - 1.0g; Nicotin Ac. - 50.0g; Vit B12 - 15.000mcg; Selenium - 0.25g e vehicle q.s.p. $-1.000 \mathrm{~g} ;{ }^{2}$ Content: $\mathrm{Mg}-16.0 \mathrm{~g} ; \mathrm{Fe}-100.0 \mathrm{~g} ; \mathrm{Zn}-100.0 \mathrm{~g} ; \mathrm{Cu}-2.0 \mathrm{~g}$; $\mathrm{Co}-2.0 \mathrm{~g}$; I $-2.0 \mathrm{~g}$ e vehicle q.s.p. $1.000 \mathrm{~g} ;{ }^{3}$ Salinomicine; ${ }^{4} \mathrm{BHT} ;{ }^{5}$ Virginiamicine ; ${ }^{6}$ Allzyme ${ }^{\mathbb{B}} \mathrm{SSF}$ as multienzimatic complex supplementation following the label recomentation and washed sand as inert. 
Table 2. Percentual and calculated composition of experimental diets used from 8 to $21 \mathrm{~d}$-old.

\begin{tabular}{|c|c|c|c|c|c|}
\hline \multirow{2}{*}{ Ingredient $\left(\mathrm{g} \cdot \mathrm{kg}^{-1}\right)$} & \multicolumn{5}{|c|}{ Sunflower level of inclusion } \\
\hline & 0 & 4 & 8 & 12 & 16 \\
\hline Corn grain & 585.37 & 579.21 & 566.09 & 560.05 & 544.17 \\
\hline Soybean meal & 333.78 & 284.94 & 247.15 & 198.37 & 165.05 \\
\hline Sunflower meal & 00.0 & 40.00 & 80.00 & 120.00 & 160.00 \\
\hline Corn gluten $60 \%$ & 14.72 & 25.33 & 29.81 & 40.14 & 42.00 \\
\hline Soy oil & 25.58 & 29.32 & 35.80 & 39.49 & 47.05 \\
\hline Dicalcium & 15.49 & 13.82 & 12.00 & 10.33 & 8.46 \\
\hline Limestone & 9.48 & 10.51 & 11.57 & 12.60 & 13.68 \\
\hline Salt & 4.82 & 4.83 & 4.83 & 4.84 & 4.84 \\
\hline DL-methionine & 3.02 & 2.76 & 2.53 & 2.28 & 2.07 \\
\hline L-lysine $\mathrm{HCl}$ & 3.01 & 3.70 & 4.11 & 4.80 & 5.11 \\
\hline L-threonine & 0.82 & 0.87 & 0.88 & 0.93 & 0.93 \\
\hline L-valine & 0.47 & 0.53 & 0.56 & 0.63 & 0.65 \\
\hline L-arginine & 0.30 & 0.85 & 1.19 & 1.74 & 2.00 \\
\hline L-tryptophane & 0.00 & 0.00 & 0.00 & 0.14 & 0.21 \\
\hline L-isoleucine & 0.00 & 0.18 & 0.33 & 0.52 & 0.65 \\
\hline Vitamin suplement $^{1}$ & 1.00 & 1.00 & 1.00 & 1.00 & 1.00 \\
\hline Mineral suplement ${ }^{2}$ & 0.50 & 0.50 & 0.50 & 0.50 & 0.50 \\
\hline Choline chloride $60 \%$ & 0.60 & 0.60 & 0.60 & 0.60 & 0.60 \\
\hline Anticoccidial $^{3}$ & 0.60 & 0.60 & 0.60 & 0.60 & 0.60 \\
\hline Antioxidant ${ }^{4}$ & 0.20 & 0.20 & 0.20 & 0.20 & 0.20 \\
\hline Growth promoter ${ }^{5}$ & 0.05 & 0.05 & 0.05 & 0.05 & 0.05 \\
\hline 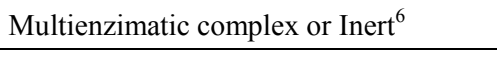 & 0.20 & 0.20 & 0.20 & 0.20 & 0.20 \\
\hline \multicolumn{6}{|l|}{ Calculated composition } \\
\hline Metabolizable Energy $\left(\mathrm{kcal} . \mathrm{kg}^{-1}\right)$ & 3050 & 3050 & 3050 & 3050 & 3050 \\
\hline Crude Protein $\left(\mathrm{g} \cdot \mathrm{kg}^{-1}\right)$ & 212.00 & 212.00 & 212.00 & 212.00 & 212.00 \\
\hline Calcium $\left(\mathrm{g} \cdot \mathrm{kg}^{-1}\right)$ & 8.41 & 8.41 & 8.41 & 8.41 & 8.41 \\
\hline Available phosphorous (g. $\left.\mathrm{kg}^{-1}\right)$ & 4.01 & 4.01 & 4.01 & 4.01 & 4.01 \\
\hline Sodium $\left(g \cdot \mathrm{kg}^{-1}\right)$ & 2.10 & 2.10 & 2.10 & 2.10 & 2.10 \\
\hline Cloride $\left(\mathrm{g} \cdot \mathrm{kg}^{-1}\right)$ & 3.40 & 3.38 & 3.36 & 3.34 & 3.32 \\
\hline Potassium $\left(\mathrm{g} \cdot \mathrm{kg}^{-1}\right)$ & 7.83 & 7.56 & 7.46 & 7.22 & 7.17 \\
\hline Neutral detergent fiber - NDF (g.kg $\left.{ }^{-1}\right)$ & 116,80 & 124,13 & 131,77 & 139,11 & 146,87 \\
\hline Acid detergente fibre - ADF (g.kg $\left.{ }^{-1}\right)$ & 47,99 & 53,67 & 59,49 & 65,16 & 71,01 \\
\hline Digestible Lysine $\left(\mathrm{g} \cdot \mathrm{kg}^{-1}\right)$ & 12.17 & 12.17 & 12.17 & 12.17 & 12.17 \\
\hline Digestible Methyonine + Cystin $\left(\mathrm{g} \cdot \mathrm{kg}^{-1}\right)$ & 8.76 & 8.76 & 8.76 & 8.76 & 8.76 \\
\hline Digestible Threonine $\left(\mathrm{g} \cdot \mathrm{kg}^{-1}\right)$ & 7.91 & 7.91 & 7.91 & 7.91 & 7.91 \\
\hline Digestible Valine $\left(\mathrm{g}^{\mathrm{kg}} \mathrm{kg}^{-1}\right)$ & 9.37 & 9.37 & 9.37 & 9.37 & 9.37 \\
\hline Digestible Isoleucine $\left(\mathrm{g} \cdot \mathrm{kg}^{-1}\right)$ & 8.17 & 8.16 & 8.16 & 8.16 & 8.16 \\
\hline Digestible Arginine $\left(\mathrm{g} \cdot \mathrm{kg}^{-1}\right)$ & 13.15 & 13.15 & 13.15 & 13.15 & 13.15 \\
\hline Digestible Tryptophan (g.kg $\left.{ }^{-1}\right)$ & 2.37 & 02.15 & 02.07 & 02.07 & 2.07 \\
\hline
\end{tabular}

${ }^{1}$ Content: Vit A - 10.000.000 UI; Vit D3 - 2.000.000UI; Vit E - 30.000UI; Vit B1 - 2.0g; Vit B6 - 4.0g; Pantotenic acid 12.0g; Biotine - 0.10g; Vit K3 - 3.0g; Folic acid - 1.0g; Nicotin Ac. $-50.0 \mathrm{~g}$; Vit B12 - 15.000mcg; Selenium - 0.25g e vehicle q.s.p. $-1.000 \mathrm{~g} ;{ }^{2} \mathrm{Content:} \mathrm{Mg}-16.0 \mathrm{~g} ; \mathrm{Fe}-100.0 \mathrm{~g} ; \mathrm{Zn}-100.0 \mathrm{~g} ; \mathrm{Cu}-2.0 \mathrm{~g} ; \mathrm{Co}-2.0 \mathrm{~g} ; \mathrm{I}-2.0 \mathrm{~g}$ e vehicle q.s.p. $1.000 \mathrm{~g} ;{ }^{3}$ Salinomicine; ${ }^{4} \mathrm{BHT} ;{ }^{5}$ Virginiamicine $;{ }^{6}$ Allzyme ${ }^{\circledR} \mathrm{SSF}$ as multienzimatic complex supplementation following the label recomentation and washed sand as inert.

At $42 \mathrm{~d}$ of age, two birds per experimental unit ( $\pm 5 \%$ average weight) were sacrificed to determine the carcass yield. The birds were identified, starved for $8 \mathrm{~h}$ and killed by cervical dislocation. The carcass yield was calculated as the ratio of the hot eviscerated carcass (without feet, neck and head) to the body weight before slaughter. The prime cut yield (whole breast, wings and legs) 
was calculated in relation to the weight of the eviscerated carcass. Abdominal fat associated with the cloaca, the bursa of Fabricius, the gizzard, the proventriculus and the adjacent abdominal muscles was removed and weighed.

The data were statistically analyzed using SAEG (System for Statistical and Genetic Analysis, Universidade Federal de Viçosa, 1997). The variables were submitted to normality (Lilliefors) and homoscedasticity (Cockerham and Bartlett) tests and the data compared by analysis of variance with subsequent polynomial regression. If a significant interaction was observed, the factors were separated and the data analyzed by the F test.

\section{RESULTS AND DISCUSSION}

The analysis of variance showed no interaction $(\mathrm{P}>0.05)$ between inclusion level of SFM and supplementation of the multienzyme complex for the performance variables from 1 to $21 \mathrm{~d}$ and from 1 to $42 \mathrm{~d}$ of age. Therefore, the effects of these two factors were independent (Table 3).

Weight gain and feed intake were increased by 3.17 and $3.24 \%$, respectively, in birds fed the diets containing exogenous enzymes compared with those fed the non-supplemented diet from 1 to $21 \mathrm{~d}$ of age. The influence of the exogenous enzymes on performance parameters observed during the initial phase were also observed from 1 to $42 \mathrm{~d}$ of age, with increases of 2.65 and $3.50 \%$ for weight gain and feed intake, respectively (Table 3). In fact, several authors have shown that enzyme supplementation can improve digestion of the fibrous contents of SFM, improving broiler performance (KOCHER et al., 2000; RAZA et al., 2009). The effective improvement in the performance parameters correlated with the enzyme combination added to the diets and the ingredients used (MALATHI; DEVEGOWDA, 2001). According to Ravindran (2013), maximal benefits from enzyme addition are achieved, if the enzymes are chosen on the basis of the substrates of the ingredients used in feed formulations.

Poultry diets are largely composed of plant-based ingredients, such as SFM, that contain non-starch polysaccharides (NSP) present in the plant cell walls. According to De Keyser et al. (2016), non-ruminants are physiologically unable to hydrolyze these NSP in their small intestine. However, Choct (2006) showed that enzymes with an affinity for NSP can result in a positive response in broiler's performance, indicating that degradation of the cell wall may facilitate the access of digestive enzymes to their substrates during the poultry gastric transit.

The weight gain varied quadratically $(\mathrm{P}<0.05)$ with the SFM level during 1 to $21 \mathrm{~d}$ of age. The data was used to establish a variability model that predicts a weight loss in the animals up to $3.51 \%$ SFM inclusion. The feed intake and feed conversion ratio linearly decreased $(\mathrm{P}<0.05)$ with increasing SFM levels during the same period (Table 3). The negative results on weight gain and feed intake can be associated with the fiber levels of SFM, which appears to be a limiting factor in poultry diets. Concerning the fiber for broilers, the physical density of the diet can change depending on the fiber content in the diets; the feed intake is decreased due to the high volume that fiber occupies in the digestive tract, which can also interfere with the water retention capacity (SUNDU; KUMAR; DINGLE, 2006). A similar linear decrease in feed intake with increasing SFM levels was reported by Tavernari et al. (2008) who tested 0 to $20 \%$ SFM dietary inclusion in birds from 1 to $21 \mathrm{~d}$ of age. However, in contrast to the current study, Tavernari et al, (2008) reported a positive effect in feed conversion ratio at all growth phases. The authors suggested this was probably due to the dietary inclusion of oil, which may have improved the digestibility of the diet (Tavernari et al., 2008). Selvaraj and Purushothaman (2004) found feed conversion rate improved in broilers from 1 to $21 \mathrm{~d}$ of age for high levels of SFM (15-20\%) but found no difference in weight gain and feed intake for up to $20 \%$ inclusion.

In general terms, the animal's performance in the initial period ( 1 to $21 \mathrm{~d}$ of age) remained similar for the entire experimental period ( 1 to $42 \mathrm{~d}$ of age), with the exception that weight gain decreased linearly $(\mathrm{P}<0.05)$ with increasing SFM levels. Thus, animals that received SFM during the initial phase failed to recover from the negative effects on the performance parameters. Immediately after hatching, the demand for energy and protein by birds is primarily directed to the expansion of the digestive tract, mainly the intestines, and when these nutrients are not provided by the diet there is a commitment of all metabolic functions of the bird to throughout its development, which can extend up to the end of the production cycle.

At $21 \mathrm{~d}$ of age, there was an SFM level/ enzyme supplementation interaction $(\mathrm{P}<0.05)$ on villus height in the duodenum and ileum, and on crypt depth in the jejunum (Table 4). For other intestinal parameters measured, the effects of SFM inclusion level and multienzyme complex supplementation were independent. There was higher villus height in the jejunum and lower crypt depth in the duodenum and ileum when enzymes were added to the diet independent of the inclusion level of SFM. With increased SFM levels, the villus height in the jejunum and the crypt depth in the duodenum and ileum decreased linearly (Table 4). 
Table 3. Performance of broilers fed diets with different levels of sunflower meal (SFM) inclusion with or without multienzyme complex supplementation.

\begin{tabular}{|c|c|c|c|}
\hline \multirow[b]{2}{*}{ Multienzyme complex } & \multicolumn{3}{|c|}{1 - 21 days } \\
\hline & Weight gain (g) & Feed intake $(\mathrm{g})$ & Feed conversion rate \\
\hline No & $622.79 \pm 0.88 \mathrm{~b}$ & $900.95 \pm 1.53 b$ & $1.446 \pm 0.001 \mathrm{a}$ \\
\hline Yes & $642.56 \pm 0.76^{\mathrm{a}}$ & $930.14 \pm 1.41 \mathrm{a}$ & $1.447 \pm 0.001 \mathrm{a}$ \\
\hline $\mathrm{P}$ value & 0.0113 & 0.0136 & 0.9208 \\
\hline \multicolumn{4}{|l|}{ SFM level (\%) } \\
\hline 0 & $656.38 \pm 1.04$ & $977.96 \pm 1.20$ & $1.491 \pm 0.002$ \\
\hline 4 & $654.75 \pm 1.12$ & $964.10 \pm 1.64$ & $1.473 \pm 0.003$ \\
\hline 8 & $655.83 \pm 1.58$ & $948.68 \pm 2.06$ & $1.447 \pm 0.002$ \\
\hline 12 & $620.31 \pm 1.67$ & $872.90 \pm 2.72$ & $1.407 \pm 0.002$ \\
\hline 16 & $576.12 \pm 1.68$ & $814.10 \pm 2.39$ & $1.414 \pm 0.002$ \\
\hline $\mathrm{P}$ value & 0.0001 & 0.0001 & 0.0001 \\
\hline Linear & 0.0001 & $0.0001^{2}$ & $0.0001^{3}$ \\
\hline Quadratic & $0.0009^{1}$ & 0.0537 & 0.4853 \\
\hline Interaction & 0.1407 & 0.7718 & 0.1564 \\
\hline \multirow[t]{2}{*}{ CV $(\%)$} & 4.16 & 4.36 & 2.74 \\
\hline & \multicolumn{3}{|c|}{$1-42$ days } \\
\hline Multienzyme complex & Weight gain $(\mathrm{g})$ & Feed intake $(\mathrm{g})$ & Feed conversion rate \\
\hline No & $2488.38 \pm 2.31 \mathrm{~b}$ & $3867.17 \pm 3.73 b$ & $1.555 \pm 0.001 \mathrm{a}$ \\
\hline Yes & $2554.38 \pm 2.01 \mathrm{a}$ & $4002.64 \pm 3.15 \mathrm{a}$ & $1.567 \pm 0.001 \mathrm{a}$ \\
\hline$P$ value & 0.0080 & 0.0004 & 0.2278 \\
\hline \multicolumn{4}{|l|}{ SFM level (\%) } \\
\hline 0 & $2591.37 \pm 3.19$ & $4076.48 \pm 4.67$ & $1.573 \pm 0.001$ \\
\hline 4 & $2566.93 \pm 4.59$ & $4002.30 \pm 4.60$ & $1.560 \pm 0.003$ \\
\hline 8 & $2554.53 \pm 5.68$ & $3998.12 \pm 8.00$ & $1.566 \pm 0.001$ \\
\hline 12 & $2486.80 \pm 5.03$ & $3868.33 \pm 8.49$ & $1.556 \pm 0.002$ \\
\hline 16 & $2407.27 \pm 4.52$ & $3730.65 \pm 8.37$ & $1.550 \pm 0.002$ \\
\hline $\mathrm{P}$ value & 0.0001 & 0.0001 & 0.6648 \\
\hline Linear & $0.0001^{4}$ & $0.0001^{5}$ & \\
\hline Quadratic & $0.0009^{1}$ & 0.0537 & \\
\hline Interaction & 0.1407 & 0.7718 & 0.1564 \\
\hline CV (\%) & 4.16 & 4.36 & 2.74 \\
\hline
\end{tabular}

${ }^{1} \mathrm{Y}=654.279+3.82116 \mathrm{x}-0.543446 \mathrm{x}^{2}\left(\mathrm{R}^{2}=0.98\right)($ minimum point $=3.51 \%)$.

${ }^{2} \mathrm{Y}=999.331-10.4729 \mathrm{x}\left(\mathrm{R}^{2}=0.90\right)$.

${ }^{3} \mathrm{Y}=1.49047-0.00551509 \mathrm{x}\left(\mathrm{R}^{2}=0.90\right)$

${ }^{4} \mathrm{Y}=2611.05-11.2080 \mathrm{x}\left(\mathrm{R}^{2}=0.90\right)$.

${ }^{5} \mathrm{Y}=4100.30-20.6406 \mathrm{x}\left(\mathrm{R}^{2}=0.91\right)$.

Means followed by the same lower case letters in the same column do not differ at the $5 \%$ of probability by the F-test in the analysis of variance.

Villus height in the duodenum was higher and crypt depth in the jejunum was lower in birds fed the diets containing exogenous enzymes than those fed the non-supplemented diet, independent of the inclusion level of SFM (Table 5). Villus height in the ileum was lower in birds fed the diets containing exogenous enzymes than those fed the non-supplemented diet, $>8 \%$ SFM inclusion (Table 5). Regarding the data observed in each group, the SFM inclusion impaired villus height in the duodenum and ileum in broilers fed supplemented diets $>12 \%$ SFM inclusion level (Table 5). Villus height in the duodenum showed a quadratic response in birds fed the supplemented diet, which predicted a higher villus height for animals fed $2.4 \%$ SFM inclusion. With increasing levels of SFM, the villus height of the duodenum and the crypt depth of the jejunum for broilers fed unsupplemented diets and villus height of the ileum for broilers fed diets containing enzymes decreased linearly (Table 5).

The impaired intestinal morphometry with SFM inclusion can be correlated with a high cell extrusion rate, decreasing the proliferation rate in response to the negative stimulus of a high fiber content in the small intestine, which also has an abrasive effect on the intestinal epithelium, by removing the mucin layer (MONTAGNE; PLUSKE; HAMPSON, 2003) and increasing endogenous losses. Generally, high-fiber ingredients have an abrasive effect on the intestinal wall (MATEOS et al., 2012), causing physical injuries, particularly to the villus apex. Hence, an increase in cellular proliferative activity in the crypt would be required to ensure an epithelial renewal compensates for the decrease in villus height. 
Table 4. Intestinal morphometry of broilers at $21 \mathrm{~d}$-old fed diets with different inclusion levels of sunflower meal (SFM) with or without multienzyme complex supplementation.

\begin{tabular}{|c|c|c|c|}
\hline \multirow[b]{2}{*}{ Multienzyme complex } & \multicolumn{3}{|c|}{ Villus height $(\mu \mathrm{m})$} \\
\hline & Duodenum & Jejunum & Ileum \\
\hline No & $1042.73 \pm 2.09 b$ & $775.60 \pm 2.01 \mathrm{~b}$ & $621.61 \pm 1.01 \mathrm{a}$ \\
\hline Yes & $1474.39 \pm 4.74 \mathrm{a}$ & $994.72 \pm 2.72 \mathrm{a}$ & $609.45 \pm 1.78 \mathrm{a}$ \\
\hline $\mathrm{P}$ value & 0.0001 & 0.0001 & 0.4942 \\
\hline \multicolumn{4}{|l|}{ SFM level (\%) } \\
\hline 0 & $1355.47 \pm 15.93$ & $998.72 \pm 9.68$ & $656.78 \pm 3.59$ \\
\hline 4 & $1437.70 \pm 16.74$ & $971.92 \pm 7.47$ & $647.18 \pm 2.29$ \\
\hline 8 & $1314.40 \pm 13.25$ & $802.55 \pm 4.92$ & $631.11 \pm 2.08$ \\
\hline 12 & $1099.36 \pm 7.36$ & $858.42 \pm 5.74$ & $570.94 \pm 4.25$ \\
\hline 16 & $1085.87 \pm 7.11$ & $794.18 \pm 6.90$ & $571.66 \pm 3.91$ \\
\hline $\mathrm{P}$ value & 0.0001 & 0.0001 & 0.0035 \\
\hline Linear & & $0.0064^{1}$ & \\
\hline Quadratic & & 0.3776 & \\
\hline Interaction & 0.0001 & 0.0585 & 0.0138 \\
\hline \multirow[t]{2}{*}{ CV $(\%)$} & 6.78 & 8.97 & 9.84 \\
\hline & \multicolumn{3}{|c|}{ Crypt depth $(\mu \mathrm{m})$} \\
\hline Multienzyme complex & Duodenum & Jejunum & Ileum \\
\hline No & $164.87 \pm 0.58 \mathrm{a}$ & $151.67 \pm 0.58 \mathrm{a}$ & $154.72 \pm 0.41 \mathrm{a}$ \\
\hline Yes & $123.04 \pm 0.42 \mathrm{~b}$ & $110.77 \pm 0.33 b$ & $116.10 \pm 0.34 \mathrm{~b}$ \\
\hline $\mathrm{P}$ value & 0.0001 & 0.0001 & 0.0001 \\
\hline \multicolumn{4}{|l|}{ SFM level (\%) } \\
\hline 0 & $162.89 \pm 1.68$ & $150.12 \pm 2.16$ & $150.69 \pm 1.46$ \\
\hline 4 & $152.09 \pm 2.26$ & $140.37 \pm 1.64$ & $138.35 \pm 1.49$ \\
\hline 8 & $144.66 \pm 1.23$ & $133.85 \pm 1.11$ & $129.99 \pm 1.58$ \\
\hline 12 & $132.16 \pm 1.23$ & $116.38 \pm 0.94$ & $131.53 \pm 1.12$ \\
\hline 16 & $127.95 \pm 1.15$ & $115.37 \pm 1.13$ & $126.51 \pm 0.91$ \\
\hline P value & 0.0068 & 0.0004 & 0.0251 \\
\hline Linear & $0.0007^{2}$ & & $0.0449^{3}$ \\
\hline Quadratic & 0.0828 & & 0.4423 \\
\hline Interaction & 0.2853 & 0.0431 & 0.2008 \\
\hline CV (\%) & 15.47 & 14.20 & 12.64 \\
\hline
\end{tabular}

${ }^{1} \mathrm{Y}=989.674-13.0645 \mathrm{x}\left(\mathrm{R}^{2}=0.75\right)$.

${ }^{2} \mathrm{Y}=161.911-2.24504 \mathrm{x}\left(\mathrm{R}^{2}=0.98\right)$.

${ }^{3} \mathrm{Y}=146.447-1.37942 \mathrm{x}\left(\mathrm{R}^{2}=0.83\right)$.

Means followed by the same lower case letters in the same column do not differ at the $5 \%$ of probability by the F-test in the analysis of variance.

The shallow crypt observed in broilers fed supplemented diets could be indicative of a decreased demand for cells with no increased nutrient requirements for maintenance. Walsh et al. (2012) assert that an increase in crypt depth can be due to an attempt to repair mucosal cell damage. Moghaddam et al. (2012) observed that increasing the levels of SFM inclusion correlated to a decrease in villus height and increase in crypt depth, in the duodenum and jejunum. Hence, the data show the positive effects of enzyme supplementation on intestinal integrity. Furthermore, a dietary enzyme supplementation is more effective than non-supplemented diets on broiler performance; the improved performance can be correlated to the positive effects of exogenous enzymes on the availability of dietary nutrients to digestive enzymes produced by the birds.

The enzymes action becomes even more pronounced considering that the availability of nutrients was critical for chickens fed diets containing SFM from $1 \mathrm{~d}$ of age. During the initial growth phase, the gastrointestinal tract undergoes a rapid rate of development. The villus height doubles within 48 hours of hatching and reaches its maximum in the duodenum within 6 to $8 \mathrm{~d}$ and after $10 \mathrm{~d}$ in the jejunum and ileum (GEYRA; UNI; SKLAN, 2001). Moreover, diet composition may produce microscopic alterations in the intestinal mucosa, and it is possible that the morphological changes in the gastrointestinal tract are associated with dietary NSP levels (YAMAUCHI, 2002). Thus, data presented in this study support the assertion of Mehri et al. (2010) that exogenous enzymes may beneficially assist the digestive process. The nutrients of plant cell walls are located within the vacuole of plant cells, encapsulated by a lipid membrane. Hence, for the nutrients to be bioavailable (absorbed during digestion within the gastrointestinal tract) they must first be bioaccessible (released from the plant cell wall matrix); however, once released there is a possibility of nutrients binding to the plant cell wall polysaccharides. A decrease in digesta viscosity and increase in villus height in the duodenum and jejunum assist nutrient digestion. 
Table 5. Interaction effects between levels of sunflower meal (SFM) and multienzyme complex supplementation for duodenum and ileum villus height and jejunum crypt depth of broilers at $21 \mathrm{~d}$-old.

\begin{tabular}{|c|c|c|c|c|c|c|}
\hline & \multicolumn{4}{|c|}{ Villus height $(\mu \mathrm{m})$} & \multicolumn{2}{|c|}{ Crypt depth $(\mu \mathrm{m})$} \\
\hline & \multicolumn{2}{|c|}{ Duodenum } & \multicolumn{2}{|c|}{ Ileum } & \multicolumn{2}{|c|}{ Jejunum } \\
\hline & \multicolumn{2}{|c|}{ Multienzyme complex } & \multicolumn{2}{|c|}{ Multienzyme complex } & \multicolumn{2}{|c|}{ Multienzyme complex } \\
\hline & Yes & No & Yes & No & Yes & No \\
\hline \multicolumn{7}{|l|}{$\begin{array}{l}\text { SFM level (\%) } \\
\text { level }(\%)(\%)\end{array}$} \\
\hline 0 & $1643.68 \mathrm{abA}$ & $1067.24 \mathrm{aB}$ & $683.31 \mathrm{aA}$ & $630.23 \mathrm{aA}$ & $115.53 \mathrm{aB}$ & 184.70abA \\
\hline 4 & $1744.07 \mathrm{abA}$ & $1131.33 \mathrm{aB}$ & $664.65 \mathrm{aA}$ & $629.70 \mathrm{aA}$ & $113.97 \mathrm{aB}$ & 166.77abcA \\
\hline 8 & $1552.22 \mathrm{bA}$ & $1076.57 \mathrm{aB}$ & $647.67 \mathrm{aA}$ & $614.55 \mathrm{aA}$ & $117.98 \mathrm{aB}$ & $149.71 \mathrm{bcA}$ \\
\hline 12 & $1226.68 \mathrm{cA}$ & $972.03 \mathrm{aB}$ & $528.13 \mathrm{bB}$ & $613.73 \mathrm{aA}$ & $104.42 \mathrm{aB}$ & $128.33 \mathrm{cA}$ \\
\hline 16 & $1205.26 \mathrm{cA}$ & $966.47 \mathrm{aB}$ & $523.47 \mathrm{bB}$ & $619.83 \mathrm{aA}$ & $101.92 \mathrm{aB}$ & $128.83 \mathrm{cA}$ \\
\hline Linear & 0.0001 & $0.0078^{2}$ & $0.0001^{3}$ & 0.6785 & 0.1301 & $0.0001^{4}$ \\
\hline Quadratic & $0.0015^{1}$ & 0.2056 & 0.4610 & 0.7926 & 0.4885 & 0.3557 \\
\hline
\end{tabular}

${ }^{1} \mathrm{Y}=1699.33-7.90669 \mathrm{x}-1.6434 \mathrm{x}^{2}\left(\mathrm{R}^{2}=0.85\right)($ maximum point $=2.40 \%)$

${ }^{2} \mathrm{Y}=1114.90-9.02109 \mathrm{x}\left(\mathrm{R}^{2}=0.64\right)$.

${ }^{3} \mathrm{Y}=700.689-11.4047 \mathrm{x}\left(\mathrm{R}^{2}=0.87\right)$

${ }^{4} \mathrm{Y}=181.709-3.75466 \mathrm{x}\left(\mathrm{R}^{2}=0.94\right)$

Means followed by the same lower case letters in the same column do not differ at the $5 \%$ of probability by the F-test in the analysis of variance.

Means followed by the same upper case letters in the same line do not differ at the $5 \%$ of probability by the F-test in the analysis of variance.

According to the carcass and cut yield results, only the thighs and legs were influenced by an interaction $(\mathrm{P}<0.05)$ between $\mathrm{SFM}$ levels and enzyme supplementation (Table 6). Wing yields linearly increased $(\mathrm{P}<0.05)$ with increasing levels of
SFM, independent of the enzyme supplementation. Thigh and leg yields were higher in birds fed the non-supplemented diet than those fed the diets containing exogenous enzymes at 8 and $12 \%$ of SFM inclusion.

Table 6. Carcass yield (\%) of broilers fed diets with different inclusion levels of sunflower meal with or without multienzyme complex supplementation until $21 \mathrm{~d}$-old.

\begin{tabular}{|c|c|c|c|c|c|}
\hline & Carcass & Breast & Wings & Thigh and leg & Abdominal fat \\
\hline \multicolumn{6}{|c|}{ Multienzyme complex } \\
\hline No & $71.57 \pm 0.03$ & $37.05 \pm 0.02$ & $10.96 \pm 0.01$ & $30.23 \pm 0.02$ & $1.30 \pm 0.005$ \\
\hline Yes & $71.08 \pm 0.02$ & $37.41 \pm 0.02$ & $10.81 \pm 0.01$ & $30.15 \pm 0.02$ & $1.36 \pm 0.004$ \\
\hline $\mathrm{P}$ value & 0.3087 & 0.3542 & 0.2526 & 0.7962 & 0.5343 \\
\hline \multicolumn{6}{|c|}{ SFM level (\%) } \\
\hline 0 & $72.53 \pm 0.07$ & $36.91 \pm 0.05$ & $10.65 \pm 0.01$ & $29,46 \pm 0.06$ & $1.37 \pm 0.012$ \\
\hline 4 & $71.71 \pm 0.07$ & $36.87 \pm 0.05$ & $10.82 \pm 0.02$ & $30,14 \pm 0.03$ & $1.35 \pm 0.013$ \\
\hline 8 & $70.82 \pm 0.08$ & $37.60 \pm 0.06$ & $10.69 \pm 0.02$ & $30,55 \pm 0.05$ & $1.39 \pm 0.009$ \\
\hline 12 & $71.12 \pm 0.05$ & $37.45 \pm 0.06$ & $10.98 \pm 0.01$ & $30,59 \pm 0.04$ & $1.25 \pm 0.008$ \\
\hline 16 & $70.45 \pm 0.04$ & $37.33 \pm 0.04$ & $11.29 \pm 0.01$ & $30,24 \pm 0.05$ & $1.27 \pm 0.017$ \\
\hline $\mathrm{P}$ value & 0.0593 & 0.6710 & 0.0125 & 0.1410 & 0.7793 \\
\hline Linear & & & $0.0021^{1}$ & & \\
\hline Quadratic & & & 0.1855 & & \\
\hline Interaction & 0.7358 & 0.4405 & 0.2457 & 0.0002 & 0.0796 \\
\hline CV $(\%)$ & 2.97 & 4.59 & 5.10 & 4.52 & 29.08 \\
\hline
\end{tabular}

${ }^{1} \mathrm{Y}=10.6021+0.0355295 \mathrm{x}\left(\mathrm{R}^{2}=0.76\right)($ maximum point $=9.64 \%)$.

According to the carcass yield results, SFM supplementation during the initial growth phase $(1-21 \mathrm{~d})$ had no negative effects at the end of the rearing period. Similarly, Tavernari et al. (2008) reported that 0 and $20 \%$ SFM levels, with or without enzyme supplementation, did not have any 
significant effect on carcass and cut yields. Broilers receiving enzyme supplementation had lower legs yield, which can be associated with an increase in bioaccessible protein, providing equal amino acid at all SFM levels. On the contrary, in diets without the enzyme supplement, the levels of amino acids supplied were different. In particular, sulfur-containing amino acids were found in large quantities in the SFM composition (OLIVEIRA et al., 2014), which is highly correlated to the synthesis of body protein but not with the specificity than lysine provides to the broilers breast. Thus, a high sulfur-containing amino acid intake causes improvement in wing and leg yields.

Table 7. Interaction effects between levels of sunflower meal (SFM) and multienzyme complex supplementation for leg yield (\%) of broilers fed experimental diets until $21 \mathrm{~d}$-old.

\begin{tabular}{lcc}
\hline & & Thigh and leg \\
\hline SFM level (\%) & No multienzyme complex & Multienzyme complex \\
\hline 0 & $28.18 \mathrm{bA}$ & $30.72 \mathrm{aA}$ \\
4 & $30.27 \mathrm{abA}$ & $30.00 \mathrm{aA}$ \\
8 & $31.35 \mathrm{aA}$ & $29.74 \mathrm{aB}$ \\
12 & $31.37 \mathrm{aA}$ & $29.80 \mathrm{aB}$ \\
16 & $29.98 \mathrm{abA}$ & $30.49 \mathrm{aA}$ \\
\hline P value & & 0.6844 \\
Linear & 0.0026 & 0.1076 \\
Quadratic & $0.0001^{1}$ & \\
\hline
\end{tabular}

${ }^{1} \mathrm{Y}=28.1512+0.688901 \mathrm{x}-0.0357202 \mathrm{x}^{2}\left(\mathrm{R}^{2}=0.99\right)$

Means followed by the same lower case letters in the same column do not differ at the $5 \%$ of probability by the F-test in the analysis of variance.

Means followed by the same upper case letters in the same line do not differ at the $5 \%$ of probability by the F-test in the analysis of variance.

\section{CONCLUSION}

Based on weight gain, up to $3.51 \%$ SFM can be added to the diets of broilers. SFM inclusion impaired some performance variables and intestinal morphometry but did not affect carcass yield. However, supplementation of the diet with a multienzyme complex counteracted the negative performance and intestinal morphometry effects.

\section{REFERENCES}

BRENES, A. et al. Effect of enzyme addition on the nutritive value of high oleic acid sunflower seeds in chicken diets. Poultry Science, Savoy, v. 87, n. 11, p. 2300-2310, 2008.

CHOCT, M. Enzymes for the feed industry: past, present and future. World's Poultry Science Journal, Cambridge, v. 62, n. 1, p. 5-16, 2006.

DE KEYSER, K. et al. High dosing NSP enzymes for total protein and digestible amino acid reformulation in a wheat/corn/soybean meal diet in broilers. The Journal of Applied Poultry Research, Savoy, v. 25, n. 2, p. 239-246, 2016.

GEYRA, A., UNI, Z., SKLAN, D. The effect of fasting at different ages on growth and tissue dynamics in the small intestine of the young chick. British Journal of Nutrition, Edinburg, v. 86, n. 1, p. 53-61, 2001.
KOCHER, A. et al. The effects of enzyme addition to broiler diets containing high concentrations of canola or sunflower meal. Poultry Science, Savoy, v. 79, n. 12, p. 1767-1774, 2000.

LUNA, L. G. Manual of the histologic staining methods of the armed forces institute of pathology. 3.ed. New York : McGraw Hill Book, 1968. $258 \mathrm{p}$.

MALATHI, V.; DEVEGOWDA, G. In vitro evaluation of nonstarch polyssacharide digestibility of feed ingredients by enzymes. Poultry Science, Savoy, v. 80, n. 3, p. 302-305, 2001.

MATEOS, G. G. et al. Poultry response to high level of dietary fiber sources varying in physical and chemical characteristics. The Journal of Applied Poultry Research, Savoy, v. 21, n. 1, p. 156-174, 2012.

MEHRI, M. et al. Effects of b-Mannanase on broiler performance, gut morphology and immune system. African Journal of Biotechnology, Nairobi, v. 9, n. 37 , p. 6221-6228, 2010.

MOGHADDAM, H. N. et al. Evaluation of the nutritional value of sunflower meal and its effect on performance, digestive enzyme activity, organ weight, and histological alterations of the intestinal villi of broiler chickens. The Journal of Applied Poultry Research, Savoy, v. 21, n. 2, p. 293-304, 2012. 
MONTAGNE, L.; PLUSKE, J. R.; HAMPSON, D. J. A review of interactions between dietary fibre and the intestinal mucosa, and their consequences on digestive health in young non-ruminant animals. Animal Feed Science and Technology, Amsterdan, v. 108 , n. 1-4, p. 95-117, 2003.

MUSHTAQ, T. et al. Influence of sunflower meal based diets supplemented with exogenous enzyme and digestible lysine on performance, digestibility and carcass response of broiler chickens. Animal Feed Science and Technology, Amsterdan, v. 149, n. 3-4, p. 275-286, 2009.

OLIVEIRA, T. M. M. et al. Sunflower meal for broilers: chemical composition and metodologics amendments on determination of energetic values and digestible aminoacids. Semina: Ciências Agrárias, Londrina, v. 35, n. 6, p. 3415-3428, 2014.

RAMA RAO, S. V. et al. Sunflower seed meal as a substitute for soybean meal in comercial broiler chicken diets. British Poultry Science, London, v. 47, n. 5, p. 592-598, 2006.

RAVINDRAN, V. Feed enzymes: The science, practice, and metabolic realities. The Journal of Applied Poultry Research, Savoy, v. 22, n. 3, p. 628-636, 2013.

RAZA, S. et al. Effect of enzyme supplemented high fibre sunflower meal on performance of broilers. Pakistan Journal of Zoology, Dacca, v. 41, n. 1, p. 57-60, 2009.

ROSTAGNO, H. S. et al. Tabelas brasileiras para aves e suínos: composição de alimentos e exigências nutricionais. 3. ed. Viçosa, MG: UFV, DZO, 2011. 252 p.

SAEG. Statistical Analysis System and Genetics SAEG. Stat. Version 8.0. Universidade Federal de Viçosa, Viçosa, Minas Gerais, 1997.

SELVARAJ, R. K.; PURUSHOTHAMAN, M. R. Nutritive value of full-fat sunflower seeds in broiler diets. Poultry Science, Savoy, v. 83, n. 3, p. 441-446, 2004.

SENKOYLU, N.; DALE, N. Nutritional evaluation of a high-oil sunflower meal in broiler starter diets. The Journal of Applied Poultry Research, Savoy, v. 15, n. 1, p. $40-47,2006$.

SUNDU, B.; KUMAR, A.; DINGLE, J. Palm kernel meal in broiler diets: effect on chicken performance and health. World's Poultry Science Journal, Cambridge, v. 62, n. 2, p. 316-325, 2006.

TAVERNARI, F. C. et al. Inclusion of sunflower meal, with or without enzyme supplementation, in broiler diets. Brazilian Journal Poultry Science, Campinas, v. 10, n. 4, p. 233-238, 2008.

WALSH, M. C. et al. Controlling Salmonella infection in weanling pigs through water delivery of direct-fed microbials or organic acids: Part II. Effects on intestinal histology and active nutrient transport. Journal of Animal Science, Champaign, v. 90, n. 8, p. 2599-2608, 2012.

YAMAUCHI, K. Review of chicken intestinal villus histological alterations related with intestinal function. The Journal of Poultry Science, Tsubuka, v.39, n. 4, p. 229-242, 2002. 